\title{
MIR143 Gene
}

National Cancer Institute

\section{Source}

National Cancer Institute. MIR143 Gene. NCI Thesaurus. Code C81739.

This gene is involved in the regulation of gene expression and plays a role in the development of colorectal and bladder carcinomas as well as Burkitt lymphoma, Diffuse large B-Cell lymphoma and chronic lymphocytic leukemia. 